\title{
FUNDAMENTAL RIGHTS AND THE PROSPECT FOR DEMOCRACY IN NIGERIA
}

\author{
ChIEF F. R. A. WILLTAMS $\dagger$
}

\section{INTRODUCTION}

Today, many objective observers would agree that there is a real need, almost everywhere in Africa, for a system of government which will guarantee economic prosperity, full employment, social justice and fundamental liberties for all. After the Second World War, world opinion was overwhelmingly in favour of putting an end to the system of colonial rule and by the early 1960's the British, the French and the Belgians had granted independence to their former colonial territories in Africa and elsewhere. The British, more than the others, did their best to lay a solid foundation for independence and they made some effort, before relinquishing power, to see that their former colonial territories were provided with a constitution modeled after their own parliamentary system. These "Made in England" constitutions have had a very high mortality rate. Their average life span is about five years; it is exceptional for any of them to survive for ten years in a form recognizable as that which the British handed over on the date of independence. But, in fairness, the fault is not entirely that of our former colonial masters. In every case, the British tried to see that the constitution reflected, as far as possible, the agreement of the political leaders of the territory concerned. Bearing this in mind, it is probably more realistic to place greater blame on ourselves for the inadequacies of our constitutions at the time of independence.

I should define the scope of this lecture at the earliest possible stage. Africa has many political problems which involve the search for a just and stable government. There is the struggle for independence of the people of the remaining colonial territories administered by Portugal and Spain. There is also the struggle taking place in the Union of South Africa and in Southern Rhodesia, where Africans whose skins happen to be dark are fighting for equal civil and political rights along with their fellow citizens whose skins happen

* This article is a reprint of a speech delivered at the University of Pennsylvania as the Owen J. Roberts Memorial Lecture on March 14, 1967.

$\dagger$ President, Nigeria Bar Association. B.A., 1943, M.A. 1946, Cambridge University. Member, English and Nigerian Bars. 
to be white. This lecture is not concerned primarily with these problems, important and vital though they are to the future of the continent. I am more concerned with the constitutional problems of the new African states. I am concerned with the causes of dissatisfaction with the constitutions that came into being upon independence and the possibility of devising new constitutions capable of ensuring stable, virile and popular governments while safeguarding the fundamental rights and liberties of citizens. All these problems, however, are not entirely unconnected. Those who defend Portuguese and Spanish colonialism in Africa or advocate white supremacy in South Africa and Rhodesia, frequently point to the failure of the governments of the new African states to provide stable and incorruptible administration and to the apparent suppression or complete disregard of fundamental individual rights in those territories. They argue that such failures show what will inevitably follow the granting of independence to the remaining colonial territories or the concession of equality of political rights to black African majorities in places where white minority rule presently obtains. These arguments can be answered effectively only if the political leaders in the new African states can find a lasting solution to the political and constitutional problems that face them today. As I have neither the knowledge nor the time to deal with all the new African states in detail, I hope I shall be forgiven for taking refuge in my own country, Nigeria.

Nigeria, as a political unit, like other colonial territories in Africa, was the creation of the colonial power which administered it. Prior to European colonial incursion into Africa, there was no political unit corresponding to what is known today as Nigeria. Nigeria was a creation of the British Colonial Administration which brought together into one political entity a large number of communities many of which were warring against each other, and were at varying stages of development, with differing political and social organizations. They had nothing in common except that they were administered as one country by the British. Therefore, when the time came for the British to hand over power to the Nigerians, power was handed over to authorities who had no claim to the loyalties of the various peoples that made up Nigeria, except that they were the legitimate successors of the former British rulers. On the other hand, there can be no doubt that, by the time British rule came to an end in Nigeria, the Nigerians had become aware of the advantages of remaining together as a single political unit. There was, therefore, an element of consent in the idea of building a nation that would owe allegiance to those entrusted with the powers of a central government. Somehow the system which was 
so carefully thought out did not produce the expected results; widespread dissatisfaction with the performance of the politicians eventually led to the Army take-over in January 1966.

It would be outside the scope of this lecture to dwell too long on the political events that led to the Army take-over. I am more concerned with examining what were, in my opinion, the main causes of the failure of the government prior to the take-over by the Army. Let me say for the benefit of those who may not be familiar with it, that the Constitution adopted by Nigeria on independence was of the federal type. It is similar to the United States Constitution in its division of legislative and executive powers between the federal and regional or state governments, as well as in its guarantees of fundamental rights by constitutional provisions. However, the structure of the executive government and the relationship between the executive and the legislature is modeled on the British parliamentary system. The judiciary is assigned a similar role as that assigned to the judiciary (or perhaps I should say as your judiciary has assumed) under the United States Constitution. There is, however, a very important difference between our judiciary and your own which I will mention hereafter in connection with the interpretation of the Bill of Rights, known to us as Provisions for Fundamental Rights.

The exact form of the constitution which Nigeria will eventually adopt is yet to be finally determined. The Army leaders have stated from time to time that a constitution will not be imposed upon the people and that no constitution will come into force until it is ratified by the people in one form or another. Communal clashes resulting in bloodshed have temporarily slowed progress in this direction. It is possible that these clashes, which have resulted in loss of life and human suffering on a fairly wide scale, will have a permanent effect on the thinking of our people about the final shape of the constitution. It is, therefore, impossible to predict the final form of the constitution with any degree of certainty. However, there is no dispute among intellectual leaders in the country that the Nigerian Constitution must be based on democratic principles and that it must guarantee fundamental rights and individual liberties.

In order to appreciate fully the nature of our political problems, one must bear in mind the fact that Nigeria consists of several nationalities, popularly referred to as "tribes." The word "tribe" is bound to be misleading because the populations of some of these so-called "tribes" are larger than those of a number of small countries which exist today as sovereign states. These nationalities differ from one another in cultural traditions, social organization and language to a 
far greater extent than the nations of Europe differ one from another. To the outsider, these differences are obscured by the habit of referring to us as "Africans," or even simply as "Nigerians." The truth of the matter is, that apart from English, we have no language which can be regarded as the lingua franca nor which is used as a means of communication between members of different communal groups. The only exception is the Hausa language which is spoken fairly widely in Northern Nigeria. There are no indigenous religions common to Nigerians other than Islam and Christianity. Curiously enough, it seems that, at least on the political, linguistic and religious levels, foreign influences have promoted unity among the various nationalities in Nigeria.

Consequently, the situation in Nigeria presents the same type of problems, albeit on a more complex scale, as those which have bedevilled Greek and Turkish communities in Cyprus and English- and French-speaking communities in parts of Canada. No constitution is likely to be acceptable to the country or prove to be workable unless it takes into account the existence of various nationalities in the country. The constitution should also assuage the fear of minorities that the powers of government may be used against their communal interest. The present Army regime in Nigeria has not yet succeeded in setting up the necessary machinery for ascertaining the views of the people about the constitution. There have been, and may yet be, setbacks in their efforts to do so, but I believe that ultimately the necessary machinery will be set up. When that time comes, the question of whether Nigeria should continue as a single political entity, or perhaps in a looser federation than we had prior to January 1966, will have to be considered. While it may be impossible at this stage to prophesy what will eventually happen insofar as the form of the constitution is concerned, one can say quite definitely that there is an overwhelming desire everywhere in Nigeria for a democratic way of life. Nothing that has happened in recent months has really shaken the faith of thinking people in Nigeria on this point. And so I think it is time that $I$ proceed to examine the essentials of a democratic society. I propose to do this because, while a democratic constitution can take a variety of forms, there are certain basic principles which must be present in all.

\section{The Essentials of a Democratic Society}

It may be considered presumptuous on my part to delay you on this aspect of my lecture. After all, it was here in America that the classical definition of democratic government was first pronounced. 
But, it is important, in the light of our experiences in Nigeria, that we remind ourselves of the basic principles of democracy. In the past, we from the developing nations of Africa have paid far too much attention to the forms and structure of constitutions and not enough to their substance. We have assumed too easily that structural arrangements which ensure the maintenance of basic principles of democracy in America or the United Kingdom will adequately serve the same purpose in Africa.

In the final analysis, a democratic society is one in which those who rule are answerable to and govern with the consent of those who are ruled. This implies that the people are entitled to choose those who will make laws to order their affairs, to define the scope and extent of their authority, to prescribe the machinery for checking abuses or excesses of power and to criticize and bring legitimate pressure to bear upon those who rule them. In short, the executive and legislative authority of the state in a democratic society must be elected.

Experience in most democratic countries has taught us that those who are entrusted with the powers of government often have an almost irresistible temptation to forget the true source of their authority and to encroach upon individual rights and liberties to an extent which is not warranted by the situation with which they are dealing. For this reason, provisions are found in the constitutions of most democratic states which are designed to protect the fundamental rights and liberties of citizens against unwarranted encroachment by the government. There are a few nations, such as the United Kingdom, where the tradition among those entrusted with power is such that public opinion, or the opinion of certain professional and other associations, is a sufficient guarantee against abuses or excesses of power. In any event, it is essential in a democratic society to ensure that fundamental rights and liberties, such as the right of free speech and assembly and the right of freedom from arbitrary arrest, are not limited at the whim or caprice of the government of the day. I will return to this subject when I discuss the method adopted under the Nigerian Constitution for guaranteeing fundamental rights. It is sufficient to say at this point that in Nigeria, as in this country and India, we have adopted the method of inserting relevant provisions in the constitution.

The last, but by no means the least, basic element of a democratic society is an independent and impartial judiciary. In Nigeria this raises very difficult problems, not only in regard to appointment of judges and other judicial officers, but also of ensuring that the various communities in the country have confidence in their impartiality. At the time of independence, in October 1960, power to 
appoint judges was vested in a Judicial Service Commission. There was one Judicial Service Commission for the Federation and one for each of the regions. Each Commission was presided over by its respective Chief Justice and consisted almost entirely of other judges. The only "outsider" was the Chairman of the Public Service Commission. This arrangement continued until 1963 when the Judicial Service Commissions were abolished. Power to appoint judges for the Federation was then vested in the Prime Minister, and for the regions in their Premiers. Under the 1960 Constitution, the removal of judges could be effected only after holding a Tribunal of Enquiry into allegations of misconduct by the judge and then if, on studying the matter further, the Judicial Committee of the Privy Council advised Her Majesty the Queen in England that the judge should be removed from office for such misconduct. This procedure for removal was altered by the Republican Constitution of 1963, which provides that judges are removable from office upon presentation to the Head of State of an address by a majority of at least two-thirds of all the members of each House of the Legislature, praying that the judge in question be removed on the ground either of inability to discharge the functions of his office or of proven misbehaviour.

There is always a risk, in any democratic society, in vesting the power to appoint judges and other judicial officers in the government of the day, or in a single member thereof. Wherever such an arrangement has worked, it has been preceded by a history of highly irregular, unmeritorious or even scandalous appointments, until public or professional opinion, by constant criticism and protests, has built up a satisfactory tradition or convention. It is widely known that until the nineteenth and early part of the twentieth century, political party considerations weighed very heavily in judicial appointments to the High Court of Justice in England. ${ }^{1}$ Considering our local circumstances, I, personally, do not think it is possible for us in Africa to copy successfully the method of appointing judges employed in the United States, the United Kingdom or any other democratic state.

1 When the office of Master of the Rolls fell vacant in 1897, Lord Salisbury, the Prime Minister, wrote a letter to Lord Halsbury, the Lord Chancellor, in which he pressed the claims to that office of Sir Edward Clarke, a member of the Tory Party, referring to "the unwritten law of our party system." HEUSTON, LIVES OF THE LORD CHANCELLORS 1885-1940, at 52 (1964). He continued:

[T] here is no clearer statute in that unwritten law than the rule that party claims should always weigh very heavily in the disposal of the highest legal appointments. In dealing with them you cannot ignore the party system as you do in the choice of a general or an archbishop. It would be a breach of the tacit convention on which politicians and lawyers have worked the British Constitution together for the last 200 years. Perhaps it is not an ideal system -some day no doubt the M.R. [Master of the Rolls] will be appointed by competitive examination in Law Reports, but it is our system for the present: Ibid. and we should give our party arrangements a wrench if we throw it aside. 
An independent and impartial judiciary can only function properly with the assistance of a vigorous and fearless body of professional lawyers and advocates who are ready to give assistance to all classes of people without regard to communal pressures or prejudice. This is of particular importance in my country where occasions may arise in which, whether rightly or wrongly, a considerable section of the public will view the issues to be contested in those cases as involving a clash of communal interests. In such cases an advocate may be required to plead the cause of someone who is supposedly antagonistic to the interests of the advocate's own community, and he must be able to resist undue pressure aimed at interfering with the discharge of his professional duties and obligations. The position of a Nigerian judge is no more enviable in such situations, unless (which is hardly ever the case) he does not belong to either of the communities whose interests are supposedly involved in the litigation. In this kind of situation, the long tradition and professional code of ethics of lawyers in all common law countries are far more effective than any constitutional guarantee.

\section{Guarantees of Fundamental Rights Under the Nigerian Constitution}

As I have already stated, it is common practice to have express provisions in the constitution which guarantee fundamental rights. But these rights are subject to limitations, and in any democratic society it is sometimes permissible for the authorities to restrict their full exercise in the interest of public security, safety, morality and health, or in the interest of the reputation of others. Broadly speaking, the United States Constitution has left it to the judiciary to work out the extent of permissible limitation of fundamental rights. However, your courts have been concerned about the extent to which they can define the scope of permissible restriction and, in a case dealing with freedom of speech, ${ }^{2} \mathrm{Mr}$. Justice Frankfurter, of your Supreme Court, has said:

History teaches that the independence of the judiciary is jeopardized when courts become embroiled in the passions of the day and assume primary responsibility in choosing between competing political, economic and social pressures. Primary responsibility for adjusting the interests which compete in the situation before us of necessity belongs to the Congress. ${ }^{3}$ 
It seems obvious that, if the definition or delimitation of permissible restriction of fundamental rights were left entirely to the judiciary, the risk of conflict with the legislature would be heightened. While a well-established democratic society can withstand the storms and stresses of such a conflict, it would be dangerous to expect the same result in a developing democratic society, and particularly in a young nation with the complex problems present in the Nigerian situation. Accordingly, when provisions for fundamental rights were first introduced into the Nigerian Constitution, there was a deliberate policy of defining as closely as possible, in the Constitution itself, the scope of permissible restriction of those rights. It was hoped that the judiciary in Nigeria would thus be saved from the embarrassment of being accused of usurping the functions of the legislature, since its work would be confined solely to interpreting the Constitution. I am by no means certain that we succeeded in achieving our objective. In the attempt to define the scope of permissible restriction, the exceptions to the rights appeared to take up more space than the rights themselves, and a lawyer in this country, looking at the text of our Constitution, is reputed to have remarked that it was not a Bill of Rights but a Bill of Exceptions! A more serious difficulty is that we have qualified the rights in many places by reference to undefined standards of political behavior in other democratic societies. The phrase which occurs again and again is "nothing in this section shall invalidate any law that is reasonably justifiable in a democratic society in the interest of defense, public safety, public order, etc., etc." It seems on the face of it that we are back at the point from which we took flight. I do not see how a Nigerian court can decide whether or not a particular law conforms to the prescribed standards without exercising some judgment of a political nature.

The only case in which, to my knowledge, the Nigerian Supreme Court has considered the problem is Director of Public Prosecutions v. Chike Obi. ${ }^{4}$ In that case the validity of sections 50 and 51 of the Nigerian Criminal Code, which made provision for the offense of sedition, was attacked on the ground that it was in conflict with the constitutional provision for freedom of expression. The Court took a view which is of some interest and it would be best for me to quote from the opinion of Federal Justice Brett, with whom Federal Justice Unsworth concurred. After remarking that "the courts should remember that their function is to decide whether a restriction is reasonably justifiable in a democratic society, and not to impose their own views on what the law ought to be," Federal Justice Brett continued: 
In considering the correct judicial approach, the Supreme Court of India said, in State of Madras $v$. Row (1952), S.C.R. 597:- "In evaluating such elusive factors and forming their own conception of what is reasonable in all the circumstances of a given case, it is inevitable that the social philosophy and the scale of values of the judges participating in the decision should play an important part, and the limit to their interference with legislative judgement can only be indicated by their sense of responsibility and self-restraint and the sobering reflection that the Constitution is meant not only for people of their own way of thinking but for all, and that the majority of the elected representatives of the people have, in authorising the imposition of the restrictions, considered them to be reasonable."

In similar vein Holmes, J., delivering the judgement of the Supreme Court of the United States in Missouri, Kansas and Texas Railroad $v$. May (1904), 194 U.S. 267, a case concerning the constitutional guarantee of the equal protection of the laws said:- "It must be remembered that legislatures are ultimate guardians of the liberties and welfare of the people in quite as great a degree as the Courts."

Mr. Justice Brett then stated that although sections 50 to 52 of the Nigerian Criminal Code were enacted in 1942 when there was not even a representative legislature in Nigeria, it was significant that in 1960 a representative legislature enacted as part of the Penal Code of Northern Nigeria a section dealing with sedition in substantially similar terms to sections 50 and 51 of the Nigerian Criminal Code. He concluded that:

[W] have to approach sections 50 and 51 of the Criminal Code not merely as part of the legacy of a former regime but as something of which an equivalent has been considered reasonably justifiable in a democratic society by the majority of the elected representatives of the people of the Federation. This does not in any way relieve the Court of the duty to judge for itself, but it is among the matters to be taken into consideration. ${ }^{5}$

With respect, I doubt if the opinion that I have just quoted would be of assistance in cases in which the enactment of a popularly elected legislature is being challenged. It does suggest, however, that the courts would be reluctant to upset any enactment alleged to have infringed upon fundamental rights on the ground that it is not reasonably justifiable in a democratic society. It is obvious that any such

5 Id. at 197-98. 
decision on the part of a court would at once result in a conflict with the legislature. It is pertinent to recall that the Commission which recommended the inclusion of fundamental rights in the Nigerian Constitution had its own reservations about the extent to which such rights could be enforced. The Commission, after strongly recommending in its report that suitable provisions guaranteeing fundamental rights be included in the Nigerian Constitution, went on to state:

Provisions of this kind in the Constitution are difficult to enforce and sometimes difficult to interpret. Nevertheless, we think they should be inserted. Their presence defines beliefs widespread among democratic countries and provides a standard to which appeal may be made by those whose rights are infringed. A Government determined to abandon democratic courses will find ways of violating them but they are of great value in preventing a deterioration in standards of freedom and the unobtrusive encroachment of a Government on individual rights. ${ }^{6}$

The Commission would appear to regard political sanctions as providing a more effective guarantee of fundamental rights than court proceedings. Our experience in Nigeria can hardly be said to have justified the pious hopes of the Commission in regard to the efficacy of extra-judicial sanctions. It must be conceded, however, that in advising their various governments on projected legislation, the law officers would no doubt draw attention to any glaring inconsistency with the provisions of the Constitution, including those providing for fundamental rights.

Let me give one example of the way in which a provision for fundamental rights can be ignored with apparent impunity. There has been, for some years, in Nigeria a very wide gap in educational achievement between Southern Nigeria (which is relatively more advanced) and Northern Nigeria (which is relatively backward). The federal government felt that it would be embarrassing if nearly all segments of the Federal Public Service were manned by Southerners who, in terms of overall population, are outnumbered by the Northerners. Yet, this must inevitably be the result if uniform standards of qualification are required for admission into the Public Service of the Federation. Many of us will agree that it is desirable, given present circumstances, to make the Federal Public Service not only Nigeria-wide in name but also in "look." As a result, the federal government decided to apply lower standards of qualification to

6 Report of the Minorities Commission 97 (1958). 
candidates from Northern Nigeria for purposes of admission to the Public Service. This policy is, I think, in direct conflict with the provisions of section 28 of the Nigerian Constitution which guarantees freedom from discrimination. Section 28 expressly provides that a citizen of Nigeria shall not be accorded any privilege or advantage that is not conferred on other Nigerian citizens merely because he belongs to a particular community, tribe, place of origin, etc. The policy has never been challenged in the courts, but even if it had been challenged, and the challenger had been able to get over the difficulty of establishing his locus standi to bring the proceedings, I doubt if success would have produced any effective results. The qualifications for admission to the Federal Public Service might very well have been lowered and the policy continued without the fanfare of a public statement!

It would seem that in the long run, there is considerable validity in the view that public opinion and the willingness of those in authority to respect fundamental rights are the only ultimate guarantees against undue encroachment upon individual freedom and liberty. It must be recognized that, although the courts have an important role to play in safeguarding the civil and political rights of the individual, there is a necessary limit to the power and authority of the courts in this connection. Time is needed to allow the democratic system to take root and grow in Nigeria, as has been true elsewhere, before safeguards for individual freedom can properly function.

The courts in Nigeria, deriving their tradition from the role of the British judiciary, naturally tend to take a restricted view of their function in regard to the enforcement of fundamental rights and the Constitution of Nigeria. Consequently, it is unlikely that they will ever be persuaded to nullify an enactment of the legislature on the ground that the particular legislation is not reasonably justifiable in a democratic society. I have spoken about the risk of the judiciary being accused of usurping the function of the legislature if it exercises its function of enforcing fundamental rights, or if it declares that a statute is void on the ground of inconsistency with the Constitution. In Nigeria, and I think in other nations of Africa generally, the strain of such conflict will be heightened by the fact that the politicians in control of the machinery of government are inclined to be very sensitive about their new powers and to resent any interference (real or imaginary) with the exercise of those powers. The situation is likely to be more highly charged whenever the bulk of the judiciary is composed of non-Africans, particularly nationals of the former colonial power. It is easy to regard the nullification of legislation in 
such cases not merely as the usurpation of legislative function by the judiciary, but rather as a continuation of interference by "outsiders" with the exercise of national sovereignty or the expression of the will of an independent state.

The reaction almost everywhere in Africa has been for the politicians to seek greater control over the appointment of judges and judicial officers in the hope that they can pack the bench with people who are likely to exercise a more favorable judgment whenever executive or legislative actions are challenged in the law courts. Our experience in Nigeria is that this method has, on the whole, failed to produce the results for which the politicians have hoped. This, of course, is due to the traditions and integrity of the bar from which judicial appointments are made. Professor D. V. Cowen, writing with special reference to South Africa, has said something in this connection which, I think, is probably also true of the rest of the continent:

We must not discount the force of legal training and professional tradition. It must not be forgotten that even though appointments are sometimes made to the Bench because of the political antecedents of the appointees, nevertheless when these men go on the Bench they take with them the restraints of their legal training and they cannot entirely ignore the professional opinion of their colleagues-on the Bench, at the Bar, at the Side-Bar, and in the universities. There are stories attributed to both the late Mr. Tielman Ross and the late Mr. Oswald Pirow (when they were Ministers of Justice in previous South African governments) about certain South African judges whose appointments were made on political grounds; and the Ministers found to their chagrin that the particular judges then proceeded to give decisions against the government that appointed them. "The trouble about these judges," said Ross and Pirow, "is that they get delusions of grandeur. Having acquired security, of tenure, they imagine that they were appointed on merit!" There are, in fact, numerous cases in the history of the United States Supreme Court where appointments, obviously political in character, have proved to be completely impartial, the judges in question frequently giving judgment against the administration that appointed them. ${ }^{\top}$

\section{The Prospects for Democracy in Nigeria}

After the Army take-over in January 1966, it was quite apparent that the overwhelming majority of Nigerians felt the need for a radical change in the system of government to which they had been

7 Cowen, The Foundations of Freedom 151-52 (1961). 
accustomed immediately before and after independence in October 1960. The main problem now is to devise a constitutional arrangement which will avoid the most patent abuses of the old regime. At the present time there are fears about the continued association of all the regions of Nigeria as one country. Because of the requirements of public security, Parliament remains suspended, political parties are banned and there is no civilian government. The country is administered on the basis of the 1963 Constitution, subject to such modifications as are made necessary by the fact that there is no legislature and no elected executive or legislative authority. Yet, it is believed, everywhere in the country, that the present arrangement is only temporary and that a democratic Constitution will in due course be fashioned. Much thought is being given to the form the new Constitution might take. Many people feel that some of the difficulties of the past regime can be traced to the close association between the executive authority and the legislature. This followed the pattern of the British parliamentary system. As a result of this arrangement, elections to the legislature were fought very fiercely since membership in the legislature was regarded as the first step towards appointment as Premier, Minister, or Parliamentary Secretary. If a political party won an election with a small majority, its ranks in the legislature usually were increased quickly by people seeking jobs as Ministers or Parliamentary Secretaries in the executive government. The arrangement was such that the really ambitious among those who sought election did so not because they were interested in legislative work but because they were seeking appointment as members of the executive government. Nigerian experience further shows that if there is a crisis within the party in control of the majority of the legislature, any resulting instability will affect both the legislative, and the executive arms of the government at the same time. This, indeed, is what happened in Western Nigeria in 1962 when the party to which the Premier belonged lost confidence in him and sought to move a vote in the legislature seeking his removal as Premier. I, myself, firmly believe that there should be a complete separation of the executive from the legislature under the Nigerian Constitution in order to avoid most of the difficulties to which I have referred.

No consideration of the prospects of democracy in Nigeria or, for that matter, in any of the new African states, can be complete without a discussion of the role of political parties. The recent fashion among some of our political leaders has been to advocate a one-party state as more suitable for African conditions. Nigeria, however, has become accustomed to the existence of competing political parties contesting 
regional and national elections. Unless there are compelling reasons to the contrary, it would, in my view, be unwise to set up a one-party system. Experience shows that, whenever a one-party system has been established, it has originated in the desire of a particular party to perpetuate its dominance of the country. One of the arguments made in support of a one-party system in a developing country is that it avoids the dissipation of the limited number of talents in the country. This argument assumes that the only arena for the exercise of talent is within the government or the governing party. I believe that in Nigeria, and in the new nations of Africa in general, there is a good deal of room for talent not only within but also outside the government and the governing party. It is also argued that a single party provides more stable government. In reality what is meant is that the elimination of all opposition gives the appearance of stability to the government. I think that, in the wider interests of any democratic state, there should be avenues for public criticism of the government and its administration and these cannot be effectively maintained under a one-party system. It is a short step from having a one-party system to insisting that public criticism of the government and its administration by ordinary citizens should be prohibited. Otherwise, the government would be affording to ordinary citizens a right which it must of necessity deny to members of the governing party.

Political parties, in normal circumstances, perform very useful functions in a democratic society. They provide a forum for discussing matters affecting the nation and for formulating opinions. Often they take the lead in arousing the public to matters of national concern which might otherwise pass unnoticed. Party political rivalry compels the party temporarily holding the reins of power to avoid doing things which the opposition might seize upon to discredit it before the electorate. To this extent, the existence of an opposition party is in the public interest and indeed there cannot be a true democracy without an opposition party. However a de facto one-party system is as bad as a de jure one-party system. Experience shows that the chances of an "independent" candidate winning an election are very slim. Therefore, if the opposition party is weak or passes out of existence, a virtual monopoly of all elected offices by the only surviving party will result. It is therefore vitally necessary, in the developing nations of Africa, where the tree of democracy is still young and will require cultivating for many years to come, that something be done to see that political parties which have established substantial support in the country do not die out because they lack sufficient money to finance their activities. Questionable methods have 
been employed in obtaining money to finance political parties. Nearly all the parties controlling the government have resorted to the practice of inflating contract prices and collecting the excess from the contractors for payment to party funds. Another method is to award contracts only to those contractors who are prepared to contribute an agreed percentage of the contract price to party funds. Nothing stops the politicians who actually handle the money before it reaches the party treasury, from helping themselves in the process of helping their political parties. Another method, perhaps less fraudulent, but equally indefensible, is for the party in power to promote a private company which has practically unlimited access to the receipt of public funds by way of loans with easy repayment terms. The company then makes generous grants to the political party. There can be no doubt that these practices ought to be stopped. It would, however, be a serious mistake to overlook the financial problems of political parties in developing countries or the need to see that parties in such countries do not die out simply because they cannot find money to lawfully finance activities.

This problem has been faced in democratic states such as Puerto Rico and the Federal Republic of Western Germany. The legislation in force in Puerto Rico provides that the principal political parties are entitled to receive from the government an annual grant of 75,000 dollars in non-election years and 150,000 dollars in election years. Detailed regulations ensure that the monies are spent in meeting the lawful expenses of the party. The law itself defines what qualifies a political party for the status of a "principal political party" entitled to receive grants. I fervently hope that the principle of giving financial assistance to political parties will be accepted in Nigeria. I have no doubt that some suitable formula could be found for the award of such assistance. This would certainly reduce the incidence of corrupt or questionable activities on the part of the party in control of the machinery of government. Such activities have done a great deal to bring governments into contempt and ridicule, both inside and outside Africa.

Before leaving the question of political parties, I must mention one problem to which I have already referred in passing and which has tended to bring the multi-party system into ill repute both in Nigeria and in the other new states of Africa. This is the problem of "carpet-crossing"-desertion of the political party on whose platform a member of the legislature has been elected. I think it is true to say that in $99.9 \%$ of the cases of "carpet-crossing," the crossing is from the opposition to the government party. The reason, as I 
have noted, is because the "carpet-crossers" seek appointment in the Executive arm of the government. This has, in turn, led to the appointment of far more Ministers and Parliamentary Secretaries than the country can afford, mainly because of the desire to keep "carpet-crossers" from crossing back. Indeed, in one of the regions of Nigeria, prior to January 1966, all the members of the government in the legislature held appointments either as Ministers or Parliamentary Secretaries!

The problem of "carpet-crossing" is not easy to deal with. Ultimately, the surest guarantee against such practices would be public opinion. In dealing with this problem, one comes up against the fundamental rights of freedom of assembly and freedom of association and it would surely not be right to curtail the rights of members of Parliament in this respect. Moreover, there still would remain those persons who disagree with their party on matters of major policy and who feel that they can no longer in good conscience continue to be associated with the party. One suggested solution is to provide that, when a member of Parliament resigns from his political party, his seat in the legislature must be declared vacant so that his constituency can decide whether or not they wish to continue to be represented by him. One justification for this view is that the constituency elected him on the ticket of his former political party in the first instance. Finally, I would point out that the complete separation of the legislature from the Executive is bound to reduce the incentive to "carpetcrossing."

\section{Quality of Leadership}

Nigeria cannot hope to survive as a democracy unless it is able to produce in the future leaders of high calibre to guide its affairs. This is true of all countries. A constitutional system which fails to produce the right type of leaders may well be regarded as inadequate for the objective it was designed to achieve. On the other hand, the constitution does not make the leaders. It merely lays down the rules for their selection and the regulation of their conduct as trustees of power within the State. A constitution, however perfect, cannot be regarded as a computer for selecting the most capable leaders to conduct the affairs of State. The democratic system ensures that the selection shall be made by the people themselves and, in this sense, it is with them that the ultimate responsibility for ensuring quality rests. Any failure to choose persons of the right quality must therefore be the fault of the voters and not of the constitution. The problem of ensuring the selection of leaders of quality is, in my view, intimately bound up with that of seeing to it that the electorate is given all 
possible help and facilities to exercise enlightened judgment on current issues. This implies that developments in the field of education must be accelerated and that the gap in educational advancement between Northern and Southern Nigeria must be narrowed and ultimately removed.

However, a constitution should ensure, as far as it is humanly possible to do so, that tendencies or activities which are likely to work against national interest, the stability of the government and the maintenance of principles of justice and fair play, are effectively checked. The actual machinery for accomplishing this must be specifically designed for the country concerned; otherwise, it will not function properly. In a plural society, such as Nigeria, constant attention must be paid to inter-community and inter-tribal relations and causes of friction and hostility must be identified and cured. It may well be that this kind of exercise will require the creation of some institutional arrangement free from political direction or control but dedicated to the promotion of national unity and the fostering of national loyalties. In the new nations of Africa, and certainly in Nigeria, I think the problem deserves special study and attention at the national level.

\section{Conclusion}

I am convinced that the task of devising a satisfactory constitution for the purpose of establishing a democratic system of government in the new and developing states of Africa is not beyond human ingenuity. In undertaking that task, a good deal will be learned from the experience, the successes and the mistakes, of the older democracies. Above all, we learn a great deal from our own experiences and from the mistakes that have brought us to the position where we are today. The process of finding a solution is not going to be smooth and one must not develop undue pessimism as a result of political crises, revolutions or breakdowns in the machinery of government. However distressing some of these events may be, they should be regarded as necessary evils in the process of educating the general public. The events which led to the downfall of the Nkruma regime in Ghana may have been the most effective way of demonstrating the fact that the over-concentration of power in the hands of one man is not the right solution for the problem of establishing stable government in African countries. Similarly, the idea of establishing a one-party state in Sierra Leone almost became a reality and was only abandoned in the face of an abortive revolution. ${ }^{8}$ Arbitrary arrests, unjust imprison-

$8 \mathrm{~A}$ successful revolution in fact later took place in Sierra Leone after this lecture was delivered. Its immediate cause was a dispute as to whether the Governor General had acted rightly in calling upon the leader of opposition to form the government after the 1967 general elections. 
ments, unwarranted suppression of freedom of speech and other outrages on the fundamental rights and liberties of the individual may cause a good deal of suffering and distress to the victims and their relatives, but they also arouse public sympathy and disturb the conscience of many influential sections of the public inside and outside the country affected, to an extent which is never realized by those in authority. If these things do not occur at some stage in the history of a nation, it may well be that it has missed a vital and important political experience.

The success of Nigeria and other developing states of Africa in establishing stable democratic systems of government is bound to lead not only to greater economic prosperity and happiness for their people, but also to the effective silencing of the only remaining excuse of the advocates of colonialism and white supremacy in Africa. 